\title{
A Comparative Clinical Study on Effect of Matra Basti of Sudhabala Taila and Ketakyadi Taila in Janusandhigata Vata
}

\author{
Dr. Biswajit Dash ${ }^{1 *}$, Dr. R.N. Acharya ${ }^{2}$
}

${ }^{1}$ Lecturer in Panchakarma, Govt. Ayurvedic College, Bolangir, Odisha, India

${ }^{2}$ Ex. Prof. Deptt.of Panchakarma, SSN Ayurvedic College, Paikamal, Odisha, India

DOI: $10.36348 /$ sijtcm.2020.v03i05.004

| Received: 14.05 .2020 | Accepted: 23.05.2020 | Published: 28.05.2020

*Corresponding author: Dr. Biswajit Dash

\section{Abstract}

As per the ayurvedic text vayu (vata) is the main governing factor in our body as well as in the universe. Also it is mentioned that the three Doshas are predominant in different stages of our age like Kapha in Balyavastha (Childhood), Pitta in yuvavastha (Young age), Vata in Vriddhavastha (old age). That's why the degeneration process is more in old age due to the predominance of Vata Dosha in our body. Sandhivata (Osteoarthitis) is one of the common examples of the degenerative disease in old age. In India Sandhivata is more prevalent in postmenopausal age group. For the management of sandhivata vatashamak drugs, Brimhan drug, snehan-swedan and Vasti chikitsa etc are being adopted as per the condition of the disease and the patient. In the present study an effort has been made to manage Sandhivata (Osteoarthritis) with matrabasti and shaman drugs. For the study total 100 no of patients of sandhivata were taken and treated with matrabasti with Sudhabala taila and ketakyadi taila. After treatment significant relief was noticed in both of the groups. In group $\mathrm{A}($ Sudhabala taila) patients $14 \%, 66 \%, 16 \%$ of patients experienced complete remission, marked improvement and moderate improvement respectively. Where as in group B (Katakyadi taila) patients the same was $10 \%$, $68 \%$, and $20 \%$ respectively. The rest $4 \%$ in group A and $2 \%$ in group B patients were experienced no relief. Hence the group B patients showed better result in comparision to group A patients. From the study it can be concluded the matrabasti has a great scope in the management of Janusandhigata vata.

Keywords: Matrabasti, Janusandhigata vata, ketakyadi taila, Sudhabalataila, Osteoarthitis.

Copyright @ 2020: This is an open-access article distributed under the terms of the Creative Commons Attribution license which permits unrestricted use, distribution, and reproduction in any medium for non-commercial use (NonCommercial, or CC-BY-NC) provided the original author and source are credited.

\section{INTRODUCTION}

Sandhigata Vata is described in all Samhita and Sangraha Grantha as a separate clinical entity under the heading of Vata Vyadhi. It is not included in 80 types of Nanatmaja Vatika Vikara by Acharya Charaka. Acharya Charaka was the first who had described the disease separately under the name of Sandhigata Anila and Acharya Sushruta was the first who has given a line of treatment of Sandhivata, first time separately.

Sandhigatavata specially occurs in vriddhavastha which is parihanikala in which dhatukshaya takes place which in turn leads to vataprakopa. Vata and asthi have ashraya-ashrayi sambandha[i], which means vata is situated in asthi. Vriddha or increased vata diminishes sneha from asthidhatu by its opposite qualities to sneha, by which khavaigunya (Rikta-Srotas) occurs in asthi which is responsible for the pathogenesis of Sandhigatavata. But modern civilization, western lifestyle, defective diet pattern has invited a number of diseases irrespective of age, sex, race etc. Osteoarthritis (Sandhivata) is one of them. Now a days this disease is commonly found in earlier age groups also.

Symptoms of Janu Sandhigatavata are sandhishula, sandhishotha, akunchana prasarana janya vedana $\left.{ }^{[i i}\right]$, hanti sandhi gati, stambha and atopa $\left[{ }^{\mathrm{iii}}\right]$ described by various Acharya. Symptoms of Janu Sandhigatavata are similar to that of osteoarthritis i.e. joint pain, swelling, stiffness, disability and crepitation over joint. Here, sandhishula, sandhishotha are due to vata prakopa and special type of shotha i.e. vatapurna driti sparsha or atopa indicate vata dominancy. Akunchana prasaranjanya vedana and hanti sandhi gati occur due to kaphakshya and vata prakopa.

Acharya Sushruta and Acharya Vagbhatta has described specific treatment for the Sandhigatavata first time i.e. Snehana, Upanaha, Agnikarma, Bandhana and Unmardana. Acharya Charaka has mentioned repeated use of Snehana, Svedana, Basti and Mridu Virechana 
for the treatment of Vatavyadhi in general. He has not mentioned specific treatment for Sandhigatavata.

Usually the onset of symptoms of this disease starts at about 4th decade of life which according to Sushruta is Hani stage of Madhyama Vaya. The most commonly affected parts are knee, hip, sacroiliac, ankle joints, distal interphalangeal joint, metatarso phalangeal joint, which are weight bearing parts of the body. Disease Osteoarthritis can also occurs as a complication of some other disease or due to Dushti of Vata, Meda, Asthi and Majja are main factors which are generally seen among the patient of Janu Sandhivata.

In the treatment point of view, modern medical science treat osteoarthritis with analgesics (pain relievers), anti-inflammatory drugs and antioxidants e.g. vitamin A, B, C, E (prevent the joint from oxidative damage). Antioxidants are the substances that prevent free radical induce damage in the body.

The weight bearing joints like knee, hip, sacroiliac joints, ankle joints are commonly affected in osteoarthritis. Therefore, body weight reduction and avoiding from weight lifting is important in prevention and further worsening the disease. Muscles, ligaments and tendons are responsible for the joint stability. So surrounding tissue of the joint must be strong to prevent or cure the osteoarthritis. If they are weak, joint damage will occur soon even with the minimal stressor on the joints. Treatment of osteoarthritis should be in such a way that, which makes tissue strong. In Ayurveda, sandhishula is one of the symptoms of Mamsakshaya and Sandhisphutana is a symptom of Majjakshaya. Weak bone can't bear even normal load and it immediately gets damaged. For the present study, treatment was selected which is able to serve the entire requirement as mentioned above to treat the disease of Janu sandhigatavata.

Basti is the best therapy for the Vata saman activity. It also acts as Rasayana, vata shamak. Suddhabala taila and Ketakyadi taila described in Sahasrayogam Taila prakarana has been selected for matra Basti in the management of Sandhi Vata. With the above concept this clinical trial was undertaken in two groups. Group -A (Suddhabala taila group) In this group 50 patients were treated with SuddhaBala taila matravasti for 15 days. Group - B (Ketakyadi taila) in this group 50 patients of Janusandhigata vata were treated with Ketakyadi taila matrabasti for 15 days. Both the taila were taken from Sahasrayogam Taila Prakaran.

\section{MATERIAL \& METHODS}

The patients were collected from the Panchakarma OPD and IPD of Government Ayurvedic College, Bolangir, Odisha.

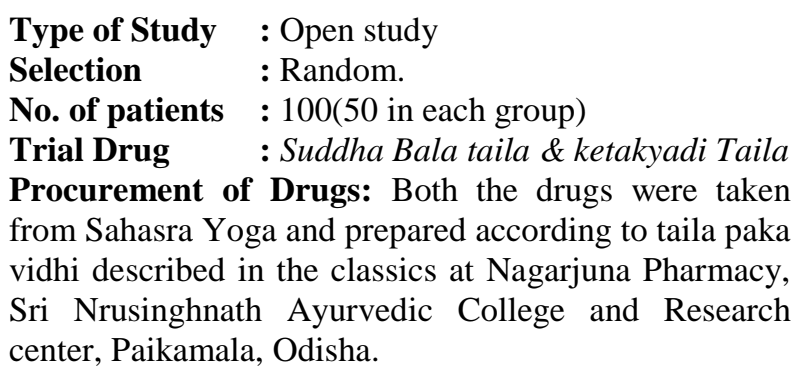

Pathya - Apathya : Was followed with respect to Janu sandhigata vata as described in literature review.

Drug, dose, duration

\begin{tabular}{|l|l|l|}
\hline & Group - A & Group- B \\
\hline Drug & Suddha Bala Taila & Ketakyadi Taila \\
\hline Dose & 1.5 pala (approx. $72 \mathrm{ml}$ ) & 1.5 pala (approx. $72 \mathrm{ml}$ ) \\
\hline Duration & 15 basti, once daily & 15 basti, once daily \\
\hline Route of administration & Anal route & Anal route \\
\hline Follow Up. & Every 15 days for one month & Every 15 days for one month \\
\hline
\end{tabular}

\section{Inclusion Criteria}

1. Age : $30-70$ yrs of age

2. Sex : Both

3. Clinically and radiographically diagnosed patient of Janu sandhigata vata.

4. Morning stiffness lasting 30 minute or less

5. Patients indicated for Matra basti.

\section{Exclusion Criteria}

1. Osteo arthritis secondary to other conditions like trama, fractures etc.

2. Complete loss of articular cartilage

3. Severe bursitis

4. Pregnant women and lactating mothers.
5. Patients who leave the treatment in between.

6. Patient with contractures of joints was not included.

7. Associated with other systemic diseases like Diabetes mellitus, Hypertension etc. which might interfere the present study.

Follow up: Follow up of the patients was done upto one month.

Investigations: Blood - DLC, TLC, $\mathrm{Hb} \%$, ESR, RBS

- $\quad$ Serum RA factor

- X-ray of affected Joint 


\section{Observations}

Table-1: (Showing overall improvement effect of therapy in 100 patients of Janusandhigata Vata)

\begin{tabular}{|l|l|c|c|c|c|}
\hline \multirow{2}{*}{ Sl. No. } & \multirow{2}{*}{ Effect of therapy } & \multicolumn{2}{|c|}{ No. Of Patients } & \multirow{2}{*}{$\begin{array}{c}\text { Total no } \\
\text { of patients }\end{array}$} & \multirow{2}{*}{ Percentage } \\
\cline { 3 - 4 } & & Group- A & Group- B & & \\
\hline 1 & Cured & 07 & 05 & 12 & 12 \\
\hline 2 & Markedly improved & 33 & 34 & 67 & 67 \\
\hline 3 & Improved & 08 & 10 & 18 & 18 \\
\hline 4 & Unchanged & 02 & 01 & 03 & 03 \\
\hline
\end{tabular}

In the present study after the therapy completed $12 \%$ patients became symptom free where as $03 \%$ of cases were having no relief. $67 \%$ of cases got maximum improvement and $18 \%$ cases got improvement in symptoms.

Table-2: (Effect of therapy on cardinal symptoms of Group - A patients)

\begin{tabular}{|c|c|c|c|c|c|c|c|c|}
\hline \multirow{2}{*}{$\begin{array}{l}\text { Cardinal } \\
\text { Symptom }\end{array}$} & \multirow{2}{*}{$\begin{array}{l}\text { Joint } \\
\text { involved }\end{array}$} & \multicolumn{2}{|c|}{ Mean Score } & \multirow{2}{*}{$\begin{array}{l}\text { \% age } \\
\text { of relief }\end{array}$} & \multirow{2}{*}{$\begin{array}{l}\text { S.D. } \\
( \pm)\end{array}$} & \multirow{2}{*}{$\begin{array}{c}\text { S.E. } \\
( \pm)\end{array}$} & \multirow[t]{2}{*}{$\mathbf{T}$} & \multirow[t]{2}{*}{$\mathbf{P}$} \\
\hline & & BT & AT & & & & & \\
\hline \multirow[t]{2}{*}{ Sandhi shula } & Lt. Knee & 2.47 & 0.56 & 73.68 & .093 & 0.19 & 9.34 & $<0.001$ \\
\hline & Rt. Knee & 2.48 & 0.68 & 70.96 & 0.92 & 0.18 & 9.50 & $<0.001$ \\
\hline \multirow[t]{2}{*}{ Sandhi sotha } & Lt. Knee & 1.25 & 0.50 & 60 & 0.46 & 0.16 & 4.58 & $<0.001$ \\
\hline & Rt. Knee & 1.58 & 0.50 & 68.42 & 0.51 & 0.14 & 7.29 & $<0.001$ \\
\hline \multirow{2}{*}{$\begin{array}{l}\text { Akunchana } \\
\text { Prasarana } \\
\text { Vedana }\end{array}$} & Lt. Knee & 2.04 & 0.50 & 73.33 & 0.74 & 0.15 & 9.50 & $<0.001$ \\
\hline & Rt. Knee & 2.13 & 0.5 & 74.46 & 0.73 & 0.15 & 10.16 & $<0.001$ \\
\hline \multirow{2}{*}{$\begin{array}{l}\text { Stambha } \\
\text { (Stiffness) }\end{array}$} & Lt. Knee & 1.37 & 0.47 & 69.23 & 0.23 & 0.05 & 18.00 & $<0.001$ \\
\hline & Rt. Knee & 1.72 & 0.50 & 74.19 & 0.46 & 0.10 & 11.76 & $<0.001$ \\
\hline \multirow{2}{*}{$\begin{array}{l}\text { Sandhi sphutan } \\
\text { (Crepetation) }\end{array}$} & Lt. Knee & 1.78 & 1.50 & 56.62 & 0.86 & 0.18 & 5.78 & $<0.001$ \\
\hline & Rt. Knee & 1.95 & 0.85 & 56.41 & 0.85 & 0.19 & 5.77 & $<0.001$ \\
\hline \multirow{2}{*}{$\begin{array}{l}\text { Sparsha } \\
\text { Asahyata } \\
\text { (Tenderness) }\end{array}$} & Lt. Knee & 1.37 & 0.31 & 73.07 & 0.47 & 0.10 & 9.24 & $<0.001$ \\
\hline & Rt. Knee & 1.72 & 0.33 & 77.42 & 0.59 & 0.14 & 9.52 & $<0.001$ \\
\hline Walkng time & & 1.35 & 0.97 & 28.14 & 0.53 & 0.25 & 18.00 & $<0.05$ \\
\hline \multirow{2}{*}{$\begin{array}{l}\text { Sandhigati } \\
\text { Asamarthya } \\
\text { (Flexion of Knee } \\
\text { joint) }\end{array}$} & Lt. Knee & 120.62 & 126.87 & 6.18 & 1.54 & 5.18 & 4 & $<0.01$ \\
\hline & Rt. Knee & 120.62 & 126.25 & 4.66 & 6.29 & 1.57 & 3.57 & $<0.01$ \\
\hline
\end{tabular}

The sandhishula (joint pain) was relieved $73.68 \%$ and $70.96 \%$ in left and right knee joint respectively. The sandhishotha (joint swelling) was relieved $60 \%$ and $68.42 \%$ in left \& right knee joint respectively $(\mathrm{p}<0.001)$. The akunchana prasaranayoh vedana (pain during movement) was relieved $73.33 \%$ and $74.46 \%$ in left \& right knee joint respectively. The Stambha (stiffness) was improved $69.23 \%$ and $74.19 \%$ in left \& right knee joint respectively, values are statistically highly significant $(\mathrm{p}<0.001)$. The $56.62 \%$ and $56.41 \%$ improvement was reported in sandhisphutana (crepitation) in left \& right knee joint respectively, values are statistically highly significant
( $\mathrm{p}<0.001)$. The sparsha asahyata (tenderness) of left \& right knee joint was improved $73.07 \%$ and $77.42 \%$ respectively, values are statistically highly significant $(\mathrm{p}<0.001)$.Effect on Left Knee Joint Flexion: The mean score of left Knee Joint Flexion before treatment was 120.62 which were increased to 126.87 after the treatment. Here $5.18 \%$ relief was noted which was statistically highly significant $(\mathrm{p}<0.01)$. Effect on Right Knee Joint Flexion: The mean score of right Knee Joint Flexion was 120.62 before treatment which was increased to 126.25 after the treatment. Here $4.66 \%$ relief was noted which was statistically highly significant $(\mathrm{p}<0.01)$. 
Table-3: (Effect of therapy on cardinal symptoms of Group-B patients)

\begin{tabular}{|c|c|c|c|c|c|c|c|c|}
\hline \multirow{2}{*}{$\begin{array}{l}\text { Cardinal } \\
\text { Symptom }\end{array}$} & \multirow{2}{*}{$\begin{array}{l}\text { Joint } \\
\text { involved }\end{array}$} & \multicolumn{2}{|c|}{ Mean Score } & \multirow{2}{*}{$\begin{array}{l}\text { \%age of } \\
\text { relief }\end{array}$} & \multirow{2}{*}{$\begin{array}{l}\text { S.D. } \\
( \pm)\end{array}$} & \multirow{2}{*}{$\begin{array}{c}\text { S.E. } \\
( \pm)\end{array}$} & \multirow[t]{2}{*}{$\mathbf{T}$} & \multirow[t]{2}{*}{$\mathbf{P}$} \\
\hline & & BT & AT & & & & & \\
\hline \multirow[t]{2}{*}{ Sandhi shula } & Lt. Knee & 2.64 & 0.77 & 67.24 & 0.81 & 0.17 & 10.23 & $<0.001$ \\
\hline & Rt. Knee & 2.45 & 0.68 & 70.37 & 0.82 & 0.18 & 9.79 & $<0.001$ \\
\hline \multirow[t]{2}{*}{ Sandhi sotha } & Lt. Knee & 1.60 & 0.20 & 87.50 & 0.50 & 0.13 & 10.69 & $<0.001$ \\
\hline & Rt. Knee & 1.65 & 0.29 & 82.14 & 0.49 & 0.12 & 11.32 & $<0.001$ \\
\hline \multirow{2}{*}{$\begin{array}{l}\text { Akunchana } \\
\text { Prasarana } \\
\text { Vedana }\end{array}$} & Lt. Knee & 2.25 & 0.60 & 71.11 & 0.59 & 0.13 & 11.96 & $<0.001$ \\
\hline & Rt. Knee & 2.19 & 0.67 & 69.56 & 0.68 & 0.15 & 10.27 & $<0.001$ \\
\hline \multirow{2}{*}{$\begin{array}{l}\text { Stambha } \\
\text { (Stiffness) }\end{array}$} & Lt. Knee & 1.69 & 0.37 & 74.07 & 0.58 & 0.14 & 8.66 & $<0.001$ \\
\hline & Rt. Knee & 1.59 & 0.35 & 77.78 & 0.66 & 0.16 & 7.67 & $<0.001$ \\
\hline \multirow{2}{*}{$\begin{array}{l}\text { Sandhi sphutan } \\
\text { (Crepetation) }\end{array}$} & Lt. Knee & 1.93 & 1.13 & 44.83 & 0.74 & 0.19 & 4.52 & $<0.001$ \\
\hline & Rt. Knee & 1.67 & 0.94 & 46.67 & 0.80 & 0.19 & 4.08 & $<0.001$ \\
\hline \multirow{2}{*}{$\begin{array}{l}\text { Sparsha } \\
\text { Asahyata } \\
\text { (Tenderness) }\end{array}$} & Lt. Knee & 1.42 & 0.26 & 77.78 & 0.74 & 0.17 & 6.53 & $<0.001$ \\
\hline & Rt. Knee & 1.47 & 0.35 & 76.00 & 0.60 & 0.14 & 7.68 & $<0.001$ \\
\hline Walkng time & & 1.35 & 0.97 & 28.14 & 0.53 & 0.25 & 18.00 & $<0.05$ \\
\hline \multirow{2}{*}{$\begin{array}{l}\text { Sandhigati } \\
\text { Asamarthya } \\
\text { (Flexion of Knee } \\
\text { joint) }\end{array}$} & Lt. Knee & 120.62 & 126.87 & 5.18 & 6.18 & 1.54 & 4 & $<0.01$ \\
\hline & Rt. Knee & 120.62 & 126.25 & 4.66 & 6.29 & 1.57 & 3.57 & $<0.01$ \\
\hline
\end{tabular}

The Sandhishula was, relieved $67.24 \%$ and $70.37 \%$ in left and right knee joint respectively. The Sandhi shotha, was improved $87.50 \%$ and $82.14 \%$ in left and right knee joint respectively. The ankuchan prasarana vedana was improved $71.11 \%$ and $69.56 \%$ in left and right knee joints respectively. The Stambha (Stiffness) was relieved $74.07 \%$ and $77.78 \%$ in left \& right knee joint which is statistically significant $(\mathrm{p}<0.001)$. Sandhisphutan ( crepitation) was improved $44.83 \%$ and $46.67 \%$ in left \& right knee joint which is statistically significant $(\mathrm{p}<0.001)$. Sparsha asahyata was improved $77.78 \%$ and $76.00 \%$ respectively. All the values are statistically highly significant $(\mathrm{p}<0.001)$. Effect on Left Knee Joint Flexion: The mean score of left Knee Joint Flexion before treatment was 120.62 which were increased to 126.87 after the treatment. Here $5.18 \%$ relief was noted which was statistically highly significant $(\mathrm{p}<0.01)$. Effect on Right Knee Joint Flexion: The mean score of right Knee Joint Flexion was 120.62 before treatment which was increased to 126.25 after the treatment. Here $4.66 \%$ relief was noted which was statistically highly significant $(\mathrm{p}<0.01)$.

Table-4: (Percentage of relief in cardinal symptoms of both Group patients)

\begin{tabular}{|c|c|c|c|c|c|}
\hline \multirow{2}{*}{$\begin{array}{l}\text { Cardinal } \\
\text { Symptoms }\end{array}$} & \multirow{2}{*}{ Joint } & \multicolumn{2}{|l|}{ Group - A } & \multicolumn{2}{|l|}{ Group - B } \\
\hline & & \% of Relief & Mean \% & \% of Relief & Mean \% \\
\hline \multirow{2}{*}{ Sandhi shula } & Lt. Knee & 73.68 & \multirow[t]{2}{*}{72.32} & 67.24 & \multirow[t]{2}{*}{68.805} \\
\hline & Rt. Knee & 70.96 & & 70.37 & \\
\hline \multirow[t]{2}{*}{ Sandhi sotha } & Lt. Knee & 60 & \multirow[t]{2}{*}{64.21} & 87.50 & \multirow[t]{2}{*}{84.82} \\
\hline & Rt. Knee & 68.42 & & 82.14 & \\
\hline \multirow{2}{*}{$\begin{array}{l}\text { Akunchana } \\
\text { Prasarana } \\
\text { Vedana }\end{array}$} & Lt. Knee & 73.33 & \multirow[t]{2}{*}{73.895} & 71.11 & \multirow[t]{2}{*}{70.335} \\
\hline & Rt. Knee & 74.46 & & 69.56 & \\
\hline \multirow{2}{*}{$\begin{array}{l}\text { Stambha } \\
\text { (Stiffness) }\end{array}$} & Lt. Knee & 69.23 & \multirow[t]{2}{*}{71.71} & 74.07 & \multirow[t]{2}{*}{75.925} \\
\hline & Rt. Knee & 74.19 & & 77.78 & \\
\hline \multirow{2}{*}{$\begin{array}{l}\text { Sandhi sphutan } \\
\text { (Crepetation) }\end{array}$} & Lt. Knee & 56.62 & \multirow[t]{2}{*}{56.515} & 44.83 & \multirow[t]{2}{*}{45.75} \\
\hline & Rt. Knee & 56.41 & & 46.67 & \\
\hline \multirow{2}{*}{$\begin{array}{l}\text { Sparsha Asahyata } \\
\text { (Tenderness) }\end{array}$} & Lt. Knee & 73.07 & \multirow[t]{2}{*}{75.245} & 77.78 & \multirow[t]{2}{*}{76.89} \\
\hline & Rt. Knee & 77.42 & & 76.00 & \\
\hline Walkng time & & 28.14 & 28.14 & 28.14 & 28.14 \\
\hline \multirow{2}{*}{$\begin{array}{l}\text { Sandhigati Asamarthya } \\
\text { (Flexion of Knee joint) }\end{array}$} & Lt. Knee & 6.18 & \multirow[t]{2}{*}{5.42} & 5.18 & \multirow[t]{2}{*}{4.92} \\
\hline & Rt. Knee & 4.66 & & 4.66 & \\
\hline
\end{tabular}




\section{DISCUSSION}

were made:-

From the observations following conclusions

- In group A, 5 patients (10\%) and group B, 7 patients $(14 \%)$ got complete remission. While 30 patients $(60 \%)$ in group A, 37 patients $(74 \%)$ in group B showed markedly improvement whereas 8 patients (16\%) in group A and 10 patients (20\%) in group B showed moderately improvement. In group A 02 patients $(04 \%)$ and in Group - B, 01 patient $(02 \%)$ were found in unchanged condition. Hence, it can be said that overall effect of group B was better on the patients of Janu Sandhivata in comparison to group A.

- On comparision of the percentage of relief in different symptoms of janusandhigata vata of both the groups it was observed that the relief in Sandhishula is $72.32 \%$ and $68.805 \%$ in group A $\& B$ respectively. In Sandhisotha it was $64.21 \%$ and $84.82 \%$ respectively. In Akuncane prasarane Vedana (pain on movement) the relief was $73.895 \%$ and $70.335 \%$ in Group A \& B respectively. In Stambha (stiffness) the percentage of relief was $71.71 \%$ and $75.925 \%$ in group A \& B respectively. In the symptoms like sandhisputan(crepetation), sparsa asahatya(tenderness), sandhigati asamarthya the percentage of relief was $(56.51 \%-45.75 \%)$, (75.24\% - 76.89\%), (5.42\% - 4.92\%) in group A \& $\mathrm{B}$ respectively. In walking time both the group showed the same percentage of relief. From the above observation it can be said that both the drugs are less or more similar effect in the management of Janu sandhigata Vata.

- Matra Basti of Suddhabala Taila comprises mainly Bala, cow milk and Tila Taila. Ketakyadi taila contains Ketaki moola, Bala, AtiBala, Yava and Tila Taila. These drugs possess mainly Snigdha
Guna, Ushna Virya, Vata Kaphanashaka, Balya and Rasayana properties, thus provided significant effect on almost all the symptoms of JanuSandhigata vata. Pharmacological study also shows that these drugs also posess antiinflammatory and anti-arthritic properties.

- This was a short time trial study. But for more precise stydy more no of patients should be enrolled and a long term study with long term follow up is needed.

- However it can be concluded that both the drugs Suddhabala taila and ketakyadi taila Matra Basti are more or less having similar effect in the management of Janusandhigata Vata.

\section{CONCLUSION}

On comparision of the percentage of relief in different symptoms of janusandhigata vata of both the groups it was observed that the relief in Sandhishula is $72.32 \%$ and $68.805 \%$ in group A \&B respectively. In Sandhisotha it was $64.21 \%$ and $84.82 \%$ respectively. In Akunchane prasarane Vedana (pain on movement) the relief was73.895\% and $70.335 \%$ in Group A \& B respectively. In Stambha (stiffness) the percentage of relief was $71.71 \%$ and $75.925 \%$ in group A \& B respectively. In the symptoms like sandhisputan(crepetation), sparsa asahatya(tenderness), sandhigati asamarthya the percentage of relief was $(56.51 \%$ - $45.75 \%),(75.24 \%-76.89 \%),(5.42 \%$ $4.92 \%$ ) in group A \& B respectively. In walking time both the group showed the same percentage of relief. However it can be concluded that both the drugs Suddhabala taila and ketakyadi taila Matra Basti are more or less having similar effect in the management of Janusandhigata Vata. Matrabasti has a great scope in the management of Janusandhigata vata.

\footnotetext{
i Su. Su. $15 / 7$, A. H. Su. 11/26-28

ii vatpu[RÔ,it $\mathrm{SpzR}>$ zaew $>$ siNxgte=inle, àsar[ak...Ncnyae $>$ àuití svedna.

iii hiNt siNxgt> siNxn! c zUlaqaepaE kraeit c, (Ma. Ni. 22/21)
} 